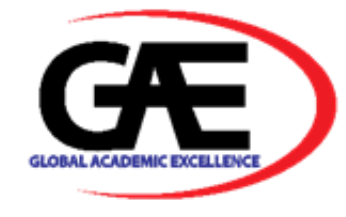

\title{
ICT-ENABLED APPLICATIONS FOR DECISION-MAKING BY THE COURTS: EXPERIENCES FROM MALAYSIA AND NIGERIA
}

\author{
Ani Munirah Mohamad ${ }^{1 *}$, Ibrahim Sule ${ }^{2}$ \\ 1 School of Law and Center for Testing, Measurement and Appraisal (CeTMA), Universiti Utara Malaysia, Malaysia \\ Email: animunirah@uum.edu.my \\ 2 Kano Campus, Nigerian Law School, Nigeria \\ Email: ibrahim.sule@nigerianlawschool.edu.ng \\ Corresponding Author
}

Article Info:

Article history:

Received date: 09.11.2020

Revised date: 15.11 .2020

Accepted date: 10.12.2020

Published date: 10.03.2021

\section{To cite this document:}

Mohamad, A. M., \& Sule, I. (2021). ICT-Enabled Applications for Decision-Making by the Courts: Experiences from Malaysia and Nigeria. International Journal of Law, Government and Communication, 6 (22), 189-196.

DOI: $10.35631 /$ IJLGC.6220018.

This work is licensed under $\underline{\mathrm{CC} B Y} 4.0$

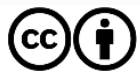

\begin{abstract}
:
In this era of internet-of-things whereby the ICT, internet, and other associated gadgets and technologies are tremendously affecting our lives, there is no gainsaying that these 'disruptive' technologies have contributed greatly to improve the pace of justice delivery all over the world. With the recent outbreak of COVID-19 all over the world, technological adoption has enhanced further. Within the context of the courts, many countries have embraced the use of ICT and the internet in their justice delivery system consequent upon which thousands of mobile phone applications and computer hardware and software are being developed. Court Rules were amended to provide for these changes and further institutionalise these changes. This conceptual paper provides insights and experiences on how ICT-enabled applications impact the decision-making processes by the courts in Malaysia and Nigeria. Hopefully, the paper would contribute to the body of knowledge on ICT adoption studies in general, and e-courts and e-justice systems in particular.
\end{abstract}

Keywords:

ICT Adoption, Decision-Aid, Decision Making, E-Court, E-Justice

\section{Introduction}

Information and communication technologies (ICT) have been embodied in various aspects of life and in various parts of the world. Industries such as education, healthcare, national defence, and telecommunications have seen tremendous penetration of ICT tools and applications, 


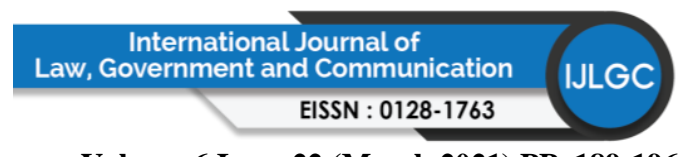

Volume 6 Issue 22 (March 2021) PP. 189-196

DOI 10.35631/IJLGC.6220018

primarily to improve the delivery system and user experiences. Particularly for the Malaysian and Nigerian contexts, ICT also made way to the judicial business. Judges of inferior and superior courts as judicial decision-makers have embraced technology in many ways in the management of their courts, including for legal research and knowledge management. Additionally, ICT applications are also utilised for dealing, interacting and collaborating with their staff and in communicating with litigants and the counsels as well as in other external decision-making, collaboration and correspondences.

Aiming to outline the ICT-enabled applications for decision making engaged by the courts of Malaysia and Nigeria, this paper begins by providing an account of the problems faced by the courts in both countries which further led to the adoption of technological applications at the courts in the first place. The main discussion of the paper centralizes upon the following section on the ICT-enabled applications for decision making by the courts in Malaysia and Nigeria. Finally, the paper outlines the future trends of ICT adoption by the courts in both countries. The paper concludes by providing a generalisation of the study and future research direction on the subject matter.

\section{ICT in the Courts of Malaysia and Nigeria}

In Malaysia, the approach taken by the government with regard to ICT is to encourage its use in public service organisations by introducing various rules and policies. Such e-Government effort and policies began way back in 1996 with the launching of a landmark project called the Multimedia Super Corridor, which attracted considerable investment and support from the world's most renowned ICT companies (Washington Times Advertising Department, 1999). The e-Government agenda include the Public Sector ICT Strategic Plan 2016-2020 which aims at enhancing the public service delivery, good governance, connected government as well as sustainable and resilient ICT infrastructure. In addition, the Electronic Government Activities Act 2007 was created to regulate the legal recognition of electronic message, the fulfilment of legal requirements of electronic messages and the communication aspects of electronic messages (Mohamad, 2018).

Within the context of the courts, the implementation of ICT began as early as 2003 with a pilot project on case management system and court recording and transcription system. However, it did not take off as planned (Zakaria, 2013). The e-court project only became successful in 2011 with the implementation of the e-Court system pilot project at 6 busy courts with the heaviest caseload in the country, being the Courts of Kuala Lumpur, Shah Alam, Ipoh, Georgetown, Johor Bharu and Putrajaya (Zakaria, 2013). Today, the nation had seen more courts in more States being equipped with ICT-enabled applications primarily to facilitate the decisionmaking by the courts.

Meanwhile, in Nigeria, with the liberalisation of the ICT market in the year 2000, the country became one of the leading countries in the telecommunications sector in Africa. With the over 148.3 million active mobile telecommunications subscriptions in 2018 there has always been pressure on the legislature to amend the existing laws and to enact new ones to bring home the challenges posed by the use, misuse and abuse of the ICT and internet (Gillwald, Odufuwa and Motobe, 2018). The judiciary in Nigeria, like other sectors embraced the ICT innovations by creating Judicial Information Technology Policy Formulation and Implementation Committee (JITPOCOM) in 2012. The committee came up with Judiciary Information Technology Policy as a comprehensive ICT policy for the country's judiciary seeking to select, adopt and 


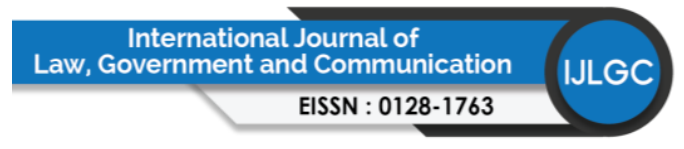

Volume 6 Issue 22 (March 2021) PP. 189-196

DOI 10.35631/IJLGC.6220018

implement "suitable ICT solutions for the Nigerian Judiciary such as a Court Case Management Systems (CCMS) and a Cloud-based email Solutions" (ANIEKWE, 2020).

Accordingly, Nigerian judicial bodies are encouraged to acquire and implement state-of-theart customised software applications and install/implement an electronic document management system in order to reduce the volumes of paper consumption and hasten information storage and retrieval (Nigerian Judiciary, 2012). This is rightly so the case for both courts and case management as well as for internal and external judicial collaboration. With this development therefore, laws establishing the courts and the Rules for operation of the courts are being amended at equally national and state levels to facilitate seamless use of technology in filing processes and in court decision making processes generally.

\section{Problems Faced by the Courts}

Various problems are faced by the courts, which later led to the judiciary in both nations of Malaysia and Nigeria to actually engage in ICT-enabled applications at the courts. First and foremost, the courts were facing problems such as backlog of cases and an extensive ageing list of unsettled cases. Apart from that, the time taken to settle any particular case is lengthy. Therefore, the government and the courts took the initiative to resort to technological applications primarily for two main purposes, (1) reduction in the backlog of cases, and (2) speedier disposal of cases (Hamin, Othman and Mohamad, 2012).

On this note, Yaacob (1981) pointed out that the most pressing problem facing the administration of justice in Malaysia then is the congestion of cases in the courts and practical difficulty of getting them disposed of as soon as possible. This was contributed by a number of factors, namely delay caused on part of the police to complete their investigations before the date of hearing, delay on part of the counsels appearing for accused persons who seek adjournments on any flimsy grounds, and delay on part of the courts when cases cannot be completed within the time allotted. Similarly, the same problems also take place in Nigeria as with the delay in case settlements resulting in a huge backlog of cases. Upon which, the Nigerian judiciary opted to engage in ICT applications for the purpose of overcoming such issues (Doma, 2016).

In both jurisdictions, the major problems faced by the courts on the backlog of cases and the ageing list of unsettled cases have motivated the exploration of various ICT applications to be engaged by the courts particularly and the entire legal fraternity generally, mainly to facilitate the decision making by the courts. The following section provides an account of the ICTenabled applications for decision making by the courts of both nations.

\section{ICT-enabled Applications for Decision Making by the Courts}

The following applications are adopted by the courts of Malaysia and Nigeria particularly in aiding the decision-making processes for matters brought before the respective courts. Primarily, the discussion approaches the issue of ICT-enable applications based on the specific purposes of the technological applications for the decision making by the courts, being (i) legal research, (ii) word processing and document automation, (iii) case and trial management, (iv) networking technologies and (v) audio/video conference systems.

In both jurisdictions, like in many countries the main work of the court is administration and dispensation of justice as determined and decided by the judge. The main function of a judge 


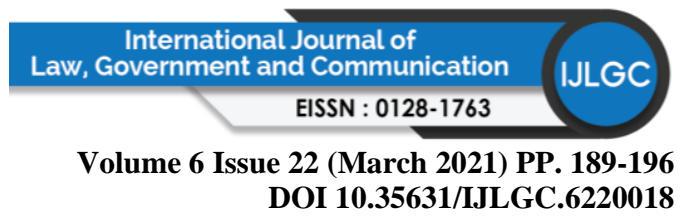

in the justice delivery involves administration of the court generally and dispensation of justice through trial of cases, judgement and execution of those judgements. Administration of the court involves dealing with and managing the court's personnel, litigants and their counsel and external collaboration with other stakeholders in the justice system like the police, prison warders, prosecutors etc. In all these, the judge being the head of the court and its sole decision maker needs to leverage technology for seamless administration of the court ecosystem, case management, judgement writing and post-judgement issues and events like record tracking and retrieval.

\section{Legal Research}

Every decision made by a judge is inevitably a by-product of the judges understanding of the facts presented before him and the law he understands based on the research he conducted. In this respect therefore and in this age ICT-enabled applications for legal research are handy. In Malaysia, the legal fraternity which includes both the courts officers as well as the legal practitioners have access to various law online databases such as Lexis Legal Research, Lawnet, Current Law Journal online, and few others, largely to facilitate the legal research of written rules, reported court judgments as well as legal articles on a certain subject matter.

Similarly, in Nigeria all judges of superior courts have research assistants specially appointed for them to help the judges in conduct of research. The judges and their respective research assistants use both online and offline legal research ICT-enabled applications and softwares like Legalpedia, LawPavillion, Toma, Compulaw, Toma Legal Retrieve, etc.

In essence, such online and offline databases resorted to by courts of both jurisdictions are mostly utlised for the purpose of finding out the legal position of a certain issue, any cases decided by the courts, as well as the journal articles on the relevant issues being considered by the courts. The results of the legal research would become a basis for the judgment of the courts and recorded as court judgments in consequentially.

\section{Word Processing And Document Automation}

Word processing is the most prevalent technology being used in both Malaysian and Nigerian courts. This is majorly due to simplicity of its use and inexpensiveness. In Nigeria, word processing application is being used in many courts by the court officials to record cases, from commencement, trial, evidence presentation to judgement; even to documenting post judgement applications and appeals.

Meanwhile, in Malaysia, general documentation tasks are carried out by using word processors, however the case registration and filing system, are generally managed by the e-filing system (EFS) of the courts (Order 63A of the Rules of Court 2012). Once the court documents are digitally stored in the registry, the EFS allows for online retrieval of service documents or any other documents, which have been previously filed in the system. If there is a need to do a file search, it could be done electronically using the EFS portal, likewise any other information relating to the case such as the schedules of cases so fixed for mention or hearing in the courts. For above-mentioned specific purposes that required payment into the courts, then the EFS facilitates such payments by allowing online payments to be made electronically to the courts' registry, hence making the entire system more efficient. 


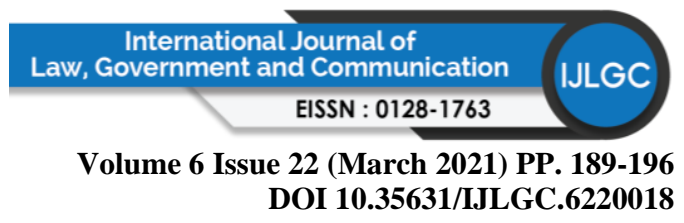

Additionally, administrative staffs also engage in the use of technologies in their work routine, specifically to enable work organisation and automation of the works. Due to the fact that some tasks are repetitive in nature, technologies such as automated registers, digital cause books (Saman and Haider, 2013), and case management systems would definitely lead to the automation of these tasks, automatic retrieval of data when needed, office management and statistical reporting. This in turn would potentially lead towards more productive works by the administrative staffs at the courts (Mohamad, Hamin and Othman, 2019).

\section{Case/Trial Management}

During trial the most important aspect of it is taking and presentation of documents and listening to witnesses and observing their demeanor. An application that is widely used by the Malaysian courts at this stage is the case management system (CMS), mainly to record and generate cause lists. CMS is a software in the courts' ICT system that manages all cases managed in the court through computer system (Hamin, Othman and Mohamad, 2013). It allows for the computerisation of court processes, retrieval of information online, easy monitoring of performance, and generates statistics automatically which in turn causes uniformity in reporting. There are a number of modules under the CMS: the registration module, the scheduling module, the master listing module and the administration module (Kuching High Court, 2010).

Traditionally, the cause book is literally in the form of a physical book for keeping information on the list of causes in relation to each of the courts. The entry into the cause book was previously done manually by the court administrative officers and approved by the respective judges presiding over the matter. Should there be any changes in the cause book, the modification was done manually by literally striking a line over the existing cause list and inserting the updated cause list beside the already deleted list (Hamin, Othman and Mohamad, 2012). With the implementation of the CMS as explained earlier, the cause list is currently prepared and used digitally via the CMS. The cause book is now defined in Order 1, rule 4 of the Rules of Court 2012 as "the book kept in the Registry or any data stored electronically in which the number of, and other details relating to, a cause or matter are entered". The digital cause list is within the purview of the administrative officers of the courts with the approval of the respective registrars and judges. The same is accessible by the solicitors and the litigants via a web portal dedicated as a platform to be used by the parties concerned.

Within the context of Nigeria, prior to 2012, there used to be some legal tussle on the recognition and acceptance of modern technologies in Nigerian Courts. The revolution brought about by the National Judicial Policy on ICT gave to to so many changes made in the rules of court in Nigeria permitting the use of ICT and electronic devices in filing and service of court processes and in evidence presentation. This is one area where Nigerian legal services indiginous companies and firms are not lagging behind. The major legal database companies Legalpedia, Law Pavillion, Judy and Toma have attempted at various times to develop a standard indiginous case management solution for Nigerian legal landscape.

One of these is the LawPavilion Court Management System which is designed specifically to help "achieve a just and timely resolution of court matters by providing judges with the tools necessary to speedily find answers, gain critical insights, and adjudicate confidently and efficiently". Some its best features include YCloud by which a judge synchronises his laptop or iPad with that of his secretary; Judicial Peer Review, by which cases decided quarterly by a 


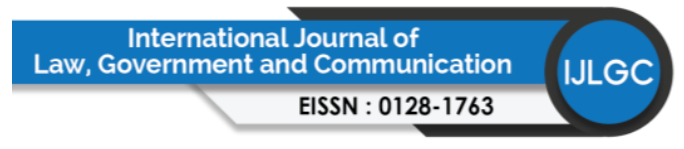

Volume 6 Issue 22 (March 2021) PP. 189-196

DOI 10.35631/IJLGC.6220018

judge would be populated, analyses and summarized and sent to National Judicial Institute for assessment; Case Status Monitor by which the judge knows the status, facts, summery, history and next line of action on every case in his court. CompuLaw is another cloud-based indiginous legal resources website with a track record of Supreme Court and other superior courts' decided cases from 1960 to date. Some of its softwares include CourtWatch.NG, Auto-retrieve.NG and Judges Access all of which help judges, lawyers and court personnel seamlessly manage their cases leveraging the use of ICT. Other areas whereby the ICT-enabled applications are affecting the decision-making process of courts in Nigeria include judgement writing skills, external collaboration.

\section{Networking Technologies}

In Nigeria, networking technologies like email were clearly accepted to be used and counsel were even mandated to provide their mandatory Supreme Court Emails on all their processes. Under Order 7 rule 11(2) (e) (i) of the Abuja Rules 2028 court can serve processes by substituted means through "e-mail or any other scientific device now known or later developed and courier service or any other means convenient to the Court". All Courts in Nigeria can now serve hearing notices via email and/or SMS except as otherwise directed by the judge" (Order 7 Rule 17 of the Abuja Rules). Service of court process by social media was also given credence recently when a High Court of Taraba State permitted service by substituted means of court process by posting to the defendants' Facebook and WhatsApp profiles, as decided in the case of Mohammad Awwaldanlami, Esq. v. Governor of Taraba State \& Twenty Four Ors (Suit No: TRST/11/2018) Unreported. The Nigerian Supreme Court in C.M.\& E.S Ltd V. Pazan Services Nig Ltd (2020) 1 NWLR (Pt 1704) 70 @ 95 recently held that "at this age of prevalence of information technology, the service of hearing notice through text message by the registrar of Court is good and sufficient notice".

Within the Malaysian context, court officials access their official electronic mail system using the top level domain name @ kehakiman.gov.my (Malaysian judiciary domain) in their official capacity to discuss and communicate various aspects of cases and proceedings. Such official electronic communications involving the courts is governed by the Electronic Government Activities Act 2007. The Act regulates the legal recognition of electronic message, the fulfilment of legal requirements of electronic messages and the communication aspects of electronic messages. In this regard, any information shall not be denied legal effect, validity or enforceability on the ground that it is wholly or partly in an electronic form. Any information shall not be denied legal effect, validity or enforceability on the ground that the information is not contained in the electronic message that gives rise to such legal effect, but is merely referred to in that electronic message, provided that the information being referred to is accessible to the person against whom the referred information might be used.

\section{Video/Virtual Conference System}

Video/virtual conference system is another innovative solution engaged by the Malaysian courts for the disposal of cases. The audio and video conference systems (AVS) are used at both High Courts of Kuala Lumpur and Sarawak for court hearings among judges, lawyers and other persons involved in the session that are at different locations. This means that judges and lawyers can save their time and travelling expenses to and out of town (Kuching High Court, 2010). By using this technology, lawyers at different locations can appear before a judge via video conference session in his hometown. The system also allows users to share documents, picture files, images and the like among those in remote locations, which constitutes a very 


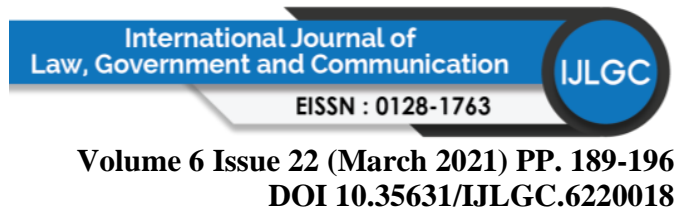

crucial feature for court hearings (Azmi, 2010). The related statutory rule for this system is Rule 1 of Rules of Court 2012 which provides that the attendance at court requires the presence of any person using electronic, mechanical or other means allowed by the Court. This implies, in effect, that the parties to the proceedings, together with their respective lawyers, may appear before the court using the AVS system for the purposes of the proceedings. Such a meeting in the AVS meeting room is legally recognised by the said rules as a meeting of the parties before the courts.

In Nigeria, although the courts are encouraged to use video/audio and virtual technology in court/trial, the technology was rarely used for the technicality and expense involved in setting it up and in managing it. However, when the COVID-19 hit hard on many countries, innovative ways of managing life emerged, from commerce to education to court sessions. Both the Chief Justice of Nigeria and the Attorney General and Minister for justice issued guidelines permitting courts to sit virtually using Skype, Zoom, Google Meet or any other technology acceptable by the court. Recently, the Supreme Court of Nigeria recently held that virtual court sessions are constitutional. By these developments, all judges in Nigeria can conduct their cases virtually through any video conferencing application agreed by the parties and accepted by the court. Witnesses can be heard, documents can be tendered, motions can be heard and judgement can be delivered not only electronically but virtually. Some of the applications being used include, Skype, Zoom, Google Meet, Cisco Webex Meet, Microsoft Teams, TeamViewer etc. These applications help in quick and seamless dispensation of justice, saving both time and resources for the court and the litigants.

\section{Future Trends for ICT-Enabled Applications at the Courts}

Some of the future trends include virtual court proceedings, most especially with the challenge posed by the COVID-19 pandemic in the year 2020. Of course, no one can say with precision when will COVID-19 go away. But one can confidently say that even if it eventually goes away, its impact will continue to change the way legal practice is conducted all over the world. There is going to be a shift from traditional manual legal practice to not only electronic or remote but virtual legal practices in all countries in general, and in Malaysia and Nigeria in particular.

\section{Conclusion}

This paper outlines the various ICT-enabled applications engaged by the courts of Malaysia and Nigeria, for the specific stages of decision-making by the courts, ranging from legal research, word processing and document automation, case and trial management and networking technologies to audio/video conference systems. In essence, the applications have proven to bring about significant changes in the way the judiciary works, such as increasing transparency and efficiency of the court processes. At each stage of the courts processes of both jurisdictions, the various tools and applications, hardwares and softwares were utilized, primarily to aid the decision making by the courts.

In this regard, future research should take a look at the potential risks and challenges of ICT within the context of the courts, and how such risks would impact on the administration of justice. These areas remain under-researched and should be an interesting direction to be explored and analysed in the future. 


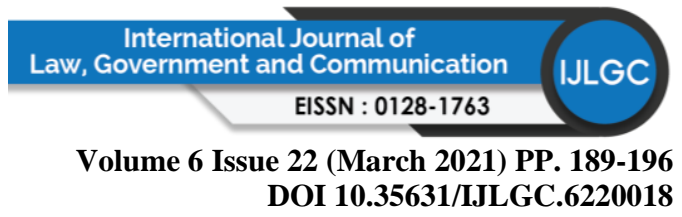

\section{References}

ANIEKWE: Legal Framework For The Use Of Information And Communications Technology (ICT) In The Nigerian Justice System: A Call For Review available at https://www.nigerianjournalsonline.com/index.php/IJOCLLEP/article/download/1098 /1082 accessed on 9th September, 2020.

Azmi, Z. (2010). Using Technology to Improve Court Performance: Malaysia's Experience. Asia Pacific Judicial Reform Forum 2010, Beijing.

Doma, Halima. "Enhancing Justice Administration in Nigeria through Information and Communications Technology, 32 J. Marshall J. Info. Tech. \& Privacy L. 89 (2016)." The John Marshall Journal of Information Technology \& Privacy Law 32, no. 2 (2016): 2.

Gillwald, Alison, Fola Odufuwa and Onkokame Mothobi, The State Of Ict In Nigeria 2018 (Policy Paper no. 3, Series 5: After Access, International Development Research Centre, 2018) available at https://researchictafrica.net/wp/wpcontent/uploads/2018/12/After-Access-Nigeria-State-of-ICT-2017.pdf accessed on 9th September, 2020

Hamin, Z., Othman, M. B., \& Mohamad, A. M. (2013). ICT support of the judiciary: The Malaysian experience.

Hamin, Z., Othman, M.B. and Mohamad, A.M., 2012, June. Benefits and achievements of ICT adoption by the high courts of Malaysia. In 2012 IEEE Symposium on Humanities, Science and Engineering Research (pp. 1233-1238). IEEE.

Kuching High Court. (2010). Brief Introduction On the Integrated Court System (ICS) in the Courts of Sabah and Sarawak. Online, accessed August, 2018.

Mohamad, Ani Munirah, Zaiton Hamin, and Mohd Bahrin Othman. "Organizational Implications of Technology Adoption at the Malaysian Civil Courts." Journal of Legal, Ethical and Regulatory Issues 22, no. 1 (2019): 1-5.

Mohamad, Ani Munirah. "Legal aspects of electronic communication involving the Malaysian courts." The European Proceedings of Social \& Behavioural Sciences (2018): 247-253.

Nigerian Judiciary Information Technology Policy Document 2012 (National Judicial $\begin{array}{lllll}\text { Council) } & \text { p. } & 27 & \text { available }\end{array}$ https://nji.gov.ng/images/PDF/JITPO_Policy_Document.pdf accessed on 6th Septmber, 2020

Saman, W. S. W. M., \& Haider, A. E-court: Information and communication technologies for civil court management Technology Management in the IT-Driven Services (PICMET), 2013 Proceedings of PICMET'13: (pp. 2296-2304): IEEE (2013), p. 231.

Siti Norma Yaacob. (1981). Administration of Justice - Procedural Reforms on Court Congestion. Current Law Journal

Washington Times Advertising Department. The Multimedia Super Corridor is Making Quantum Leaps Into the Information Age. (1999).

Zakaria, A. (2013). Review of ICT Implementation Mechanism in Judiciary of Malaysia. International Seminar on ICT Implementation in Courts, Grand Bukhara Hotel, Bukhara, Uzbekistan. 